\title{
ANKRD30A wt Allele
}

National Cancer Institute

\section{Source}

National Cancer Institute. ANKRD30A wt Allele. NCI Thesaurus. Code C54374.

Human ANKRD30A wild-type allele is located in the vicinity of 10p11.21 and is approximately $122 \mathrm{~kb}$ in length. This allele, which encodes ankyrin repeat domaincontaining protein $30 \mathrm{~A}$, may play a role in the modulation of transcription. Aberrant expression of the gene may be associated with breast and prostate cancers. 